\title{
Infestation rates of Varroa destructor and Braula coeca in the savannah honey bee (Apis mellifera scutellata)
}

\author{
Ursula Strauss ${ }^{1}$, Christian W W Pirk ${ }^{1 *}$, Vincent Dietemann ${ }^{1,2}$, Robin M Crewe $^{1}$ and Hannelie Human ${ }^{1}$
}

\author{
${ }^{1}$ Social Insect Research Group, Department of Zoology and Entomology, University of Pretoria, Private Bag X20, Hatfield, \\ Pretoria, South Africa 0028. \\ ${ }^{2}$ Agroscope, Swiss Bee Research Centre, 3003 Bern, Switzerland. \\ *Corresponding author: Email: cwwpirk@zoology.up.ac.za
}

Key words: Varroa destructor, Braula coeca, Apis mellifera scutellata, honey bee, infestation, mite, parasite

The honey bee (Apis mellifera L.) colony hosts a diversity of pathogens, parasites and pests. The introduced ectoparasite, Varroa destructor Anderson \& Trueman (Acari: Varroidae), is regarded as one of the most serious threats to honey bee health today (Rosenkranz et al., 2010). The population dynamics and negative effects of $V$. destructor have been well documented in Europe and the USA (Rosenkranz et al., 2010). In contrast, the population size and impact on colonies of Braula coeca Nitzsch (Diptera; Braulidae), a wingless fly, are less well documented. This fly is generally considered to be a minor pest (Hepburn, 1978), but a large number of individuals on queens might decrease their ability to lay eggs (Argo, 1926; Crane, 1990) and their larvae can cause physical damage to honey combs when they tunnel below the wax cappings (Hepburn, 1978; Ellis, 2008).

The presence of $V$. destructor and B. coeca has been reported in most countries around the world (Ellis and Munn, 2005). The widespread use of acaricides to control $V$. destructor has reduced the prevalence of $B$. coeca in most regions (Kulincevic et al., 1991;

Sammataro and Avitabile, 2011). However, in South Africa, few or no acaricides are used in honey bee colonies, which was confirmed in a recent survey on colony losses (Pirk et al., 2014), and B. coeca populations have been maintained.

In South Africa, little is known about B. coeca infestation rates, but the near universal presence of $V$. destructor has been confirmed (Allsopp, 2006; Strauss et al., 2013). The infestation rates of $V$. destructor and $B$. coeca were examined in adult savannah honey bees, $A$. $m$. scutellata, in order to assess whether they vary in time and whether they could pose a risk to colonies.

Adult honey bees ( $A$. m. scutellata) were collected each season from July 2010 to August 2011 from 13 apiaries (not exposed to acaricides) situated in the Gauteng region of South Africa (Strauss et al., 2013). A total of 51 colonies were sampled across seasons in six apiaries, and 33 colonies from seven apiaries were sampled only once. $V$. destructor and $B$. coeca were washed off adult honey bees (Allsopp, 2006) and counted. Infestation rates were calculated as follows: number of $V$. destructor or $B$. coeca divided by the number of honey bees per sample and multiplied by 100 . Following standard guidelines (Pirk et al., 2013), a Pearson correlation was performed to determine whether there was a correlation between $V$. destructor and B. coeca infestation rates.

For all seasons, no significant correlations $(-0.11<\mathrm{R}<0.20$, $P>0.05)$ were found in the infestation rates of $V$. destructor and $B$. coeca. $V$. destructor infestation rates were consistently higher than those of B. coeca (Fig. 1). Both species were common in A. m. scutellata colonies and the average infestation rates over all seasons were $2.1 \pm 2.3 \mathrm{~V}$. destructor and $1.2 \pm 1.5 \mathrm{~B}$. coeca per 100 adult honey bees.

A. m. scutellata colonies were infested with $V$. destructor during all seasons, but the highest rates were recorded during winter 2011, with $3.0 \pm 3.6$ mites per 100 bees. Allsopp (2006) found that the average infestation rates of untreated $A$. $m$. scutellata colonies measured during autumn and winter of 1999 were 7.7 and 1.0 mites per 100 adult honey bees, respectively. In $A$. $m$. capensis, the neighbouring subspecies, $V$. destructor infestation rates also differed between the winter of 1999 (3.5 mites per 100 adult honey bees) and 2000 (7.5 mites per 100 adult honey bees) (Allsopp, 2006). In Africanised honey bees that are also tolerant to the parasitic mite, comparable infestation rates of 3.5 mites per 100 adult honey bees were recorded (Medina et al., 2002). These figures ( $<3.5$ mites per 100 adult honey bees) correspond to those for European honey bees that survive in the presence of $V$. destructor after acaricide treatment (Genersch et al., 2010; Guzman-Novoa et al., 2010) and therefore seem to be at a level where several of the honey bee subspecies can tolerate the parasite. 
B. coeca was found across all seasons in A. m. scutellata colonies. In Benin, Paraïso et al. (2012) observed similar infestation rates as in our study that ranged from 0.3 to 4.6 individuals per $100 \mathrm{~A} . \mathrm{m}$. adansonii workers. We recorded the highest infestation rates during winter 2011. In contrast, B. coeca numbers in other regions of the world peaked at different seasons (spring and autumn in USA, Smith and Caron, 1984; summer and autumn in Jordan, Zaitoun and AlGhzawi, 2008). The climatic differences between these regions might explain the differences in $B$. coeca numbers. Indeed, varying climatic conditions not only between regions but also between years could explain the differences in the infestation rates of both $V$. destructor and B. coeca in South Africa in the winters of 2010 and 2011; with values during the first winter being lower and more comparable with the other seasons.

The lack of a significant correlation between the seasonal infestation rates of $V$. destructor and $B$. coeca, indicates that there is minimal or no direct competition between these organisms. This becomes even more apparent when considering the life history of the two organisms; $B$. coeca larvae emerge from eggs laid on honey cappings (Ellis, 2008), and are not dependent on developing honey bee brood for survival during maturation. Conversely, $v$. destructor mites depend on sealed honey bee brood for their reproductive phase and their main food source is honey bee haemolymph and not honey, pollen or food secretions as is the case with B. coeca (Ellis, 2008; Rosenkranz et al., 2010). Although the adults of both species spend a considerable time on adult honey bees, $V$. destructor prefers to attach itself to the abdomen to feed but can also be found between the head and thorax of honey bees (Bowen-Walker et al., 1997), while B. coeca rests on the thorax and moves to the head of honey bees to feed (Ellis, 2008). This suggests that competition for space on adult honey bees or for food is unlikely.
In this study, the low $V$. destructor and $B$. coeca infestation rates suggest that they do not have a significant effect on the health of the honey bee population studied. In addition, few honey bee viruses were detected in this region (Strauss et al., 2013) and this might explain why the South African A. m. scutellata population is able to survive in the presence of $V$. destructor, without treatment, 16 years after the mite was first introduced into the country.

\section{Acknowledgements}

We thank all beekeepers involved for providing samples and access to apiaries. The financial assistance of the National Research Foundation (NRF) and the University of Pretoria for this research is hereby acknowledged. Opinions expressed and conclusions arrived at, are those of the authors.

\section{References}

ALLSOPP, M (2006) Analysis of Varroa destructor infestation of southern African honey bee populations. MSc thesis, University of Pretoria; Pretoria, South Africa.

ARGO, V N (1926) Braula coeca in Maryland. Journal of Economic Entomology, 19: 170-174.

BOWEN-WALKER, P L; MARTIN, S J; GUNN, A (1997) Preferential distribution of the parasitic mite, Varroa jacobsoni Oud. on overwintering honey bee (Apis mellifera L.) workers and changes in the level of parasitism. Parasitology, 114: 151-157. http://dx.doi.org/10.1017/S0031182096008323

CRANE, A (1990) Bees and beekeeping, science, practice and world resources. Heinemann Professional Publishing Ltd; Halley Court, Jordan Hills, Oxford, UK.

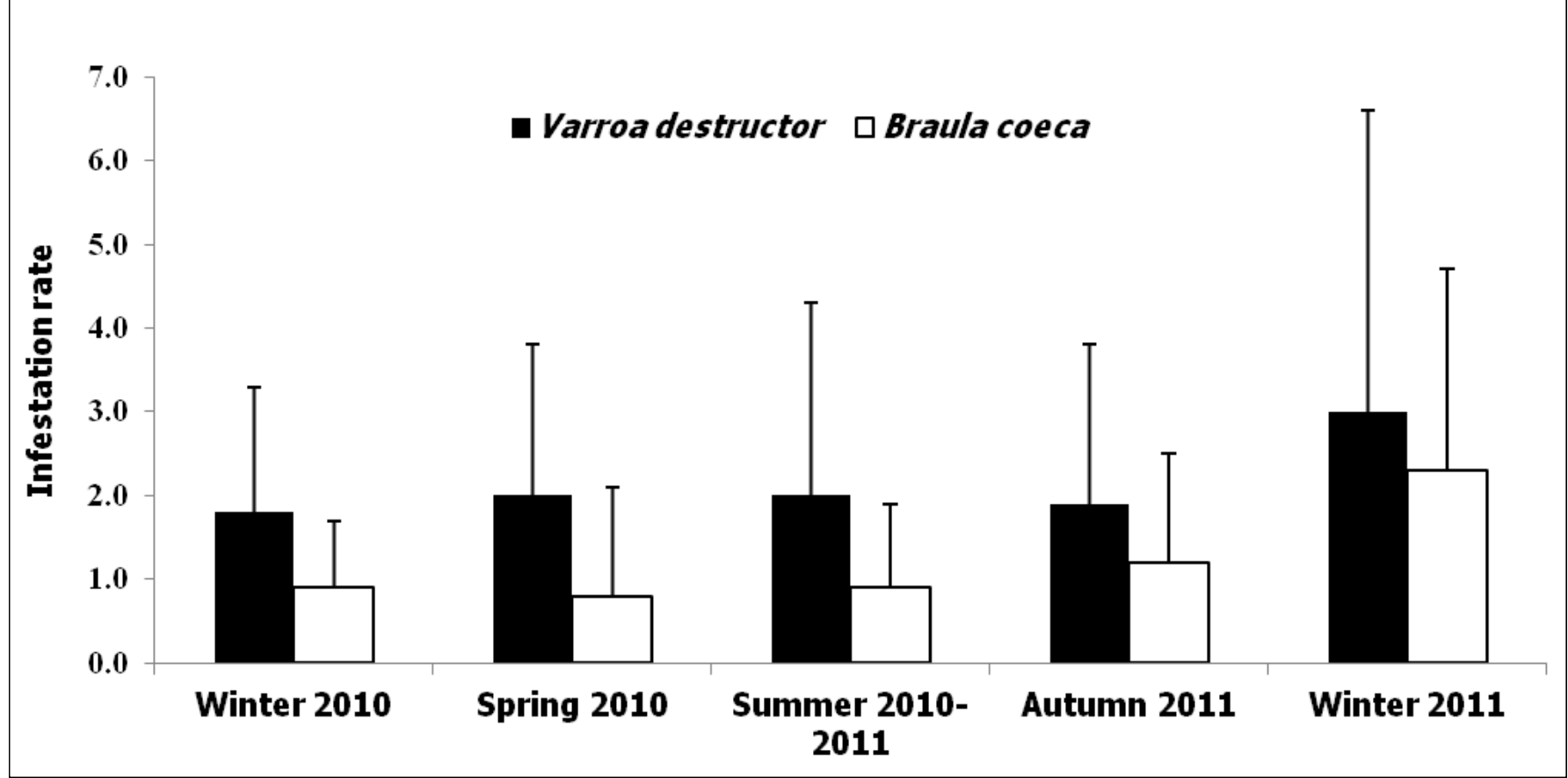

Fig. 1. Infestation rates (mean \pm SD) of Varroa destructor and Braula coeca per 100 adult honey bees in Apis mellifera scutellata colonies . 
ELLIS, J D (2008) Bee louse, bee fly, Braulid, Braula coeca Nitzsch (Diptera: Braulidae). In J L Capinera (Ed.). Encyclopaedia of Entomology. Springer; Berlin, Germany. pp. 417-419.

ELLIS, J D; MUNN, P A (2005) The worldwide health status of honey bees. Bee World, 86: 88-101.

GENERSCH, E; VON DER OHE, W; KAATZ, H; SCHROEDER, A; OTTEN, C; BÜCHLER, R; BERG, S; RITTER, W; MUHLEN, W; GISDER, S; MEIXNER, M; LIEBIG, G; ROSENKRANZ, P (2010) The German bee monitoring project: a long term study to understand periodically high winter losses of honey bee colonies. Apidologie, 41: 332-352. http://dx.doi.org/10.1051/apido/2010014

GUZMAN-NOVOA, E; ECCLES, L; CALVETE, Y; MCGOWAN, J; KELLY, P

G; CORREA-BENITEZ, A (2010) Varroa destructor is the main culprit for the death and reduced populations of overwintered honey bee (Apis mellifera) colonies in Ontario, Canada.

Apidologie, 41: 443-450. http://dx.doi.org/10.1051/apido/2009076

HEPBURN, H R (1978) The bee louse. South African Bee Journal, 50: 11-12.

KULINCEVIC, J M; RINDERER, T E; MLADJAN, V J (1991) Effects of fluvalinate and amitraz on bee lice (Braula coeca Nitzsch) in honey bee (Apis mellifera L.) colonies in Yugoslavia. Apidologie, 22: 4347. http://dx.doi.org/10.1051/apido:19910106

MEDINA, L M; MARTIN, S J; ESPINOSA-MONTAÑO, L; RATNIEKS, F L W (2002) Reproduction of Varroa destructor in worker brood of Africanized honey bees (Apis mellifera). Experimental and Applied Acarology, 27: 79-88. http://dx.doi.org/10.1023/A:1021579113907

PARAÏSO, A A; AGASSOUNON, M; DAOUDA, I-H; AMEVOIN, K; GLITHO, I A (2012) First record of Braula coeca Nitzsch (Diptera: Braulidae), a parasite of Apis mellifera adansonii in Benin. International Journal of Science and Advanced Technology, 2: 24-30.
PIRK, C W W; DE MIRANDA, J R; FRIES, I; KRAMER, M; MURRAY, T; PAXTON, R; NAZZI, F; SHUTLER, D; VAN DER STEEN, J J M; VAN DOOREMALEN, C (2013) Statistical guidelines for Apis mellifera research. In V Dietemann; J D Ellis; P Neumann (Eds) The COLOSS BEEBOOK, Volume I: standard methods for Apis mellifera research. Journal of Apicultural Research, 52(4): http://dx.doi.org/10.3896/IBRA.1.52.4.13

PIRK, C W W; HUMAN, H; CREWE, R M; VANENGELSDORP, D (2014) A survey of managed honey bee colony losses in the Republic of South Africa - 2009 to 2011. Journal of Apicultural Research, 53 (1): 35-42. http://dx.doi.org/ 10.3896/IBRA.1.53.1.03

ROSENKRANZ, P; AUMEIER, P; ZIEGELMANN, B (2010) Biology and control of Varroa destructor. Journal of Invertebrate Pathology, 103: 96-119. http://dx.doi.org/10.1016/j.jip.2009.07.016

SAMMATARO, D; AVITABILE, A (2011) The beekeeper's handbook. Cornell University Press; Ithaca, New York, USA.

SMITH, I B; CARON, D M (1984) Distribution of the bee louse Braula coeca Nitzsch in honey bee colonies and its preferences among workers, queens and drones. Journal of Apicultural Research, 23: 171-176.

STRAUSS, U; HUMAN, H; GAUTHIER, L; CREWE, R M; DIETEMANN, V; PIRK, C W W (2013) Seasonal prevalence of pathogens and parasites in the savannah honey bee (Apis mellifera scutellata). Journal of Invertebrate Pathology ,114: 45-52. http://dx.doi.org/10.1016/j.jip.2013.05.003

ZAITOUN, S; AL-GHZAWI, A A (2008) Daily number of bee louse (Braula coeca) in honey bee (Apis mellifera carnica and $A . m$. syriaca) colonies maintained under semi-arid conditions. Insect Science, 15: 563-567. http://dx.doi.org/10.1111/j.1744-7917.2008.00246.x 